\title{
New ways for an old cation
}

\author{
Martin Diener ${ }^{1}$ (D)
}

Received: 28 April 2020 / Revised: 28 April 2020 / Accepted: 6 May 2020 / Published online: 25 May 2020

(C) The Author(s) 2020, corrected publication 2021

In this issue of Pflügers Archiv European Journal of Physiology, Liebe et al. describe the properties of bTRPV3 (bovine transient receptor potential vanilloid type 3 ) channels expressed in model systems such as HEK-293 cells or Xenopus oocytes. By using a combination of different methods such as $\mathrm{pH}$ - and voltage-sensitive microelectrodes or patch-clamp recordings, they demonstrate that this channel is highly permeable for $\mathrm{NH}_{4}{ }^{+}$. This cation is produced in large amounts in the forestomach during the degradation of proteins and non-protein nitrogen compounds by microbes living in symbiosis with the ruminant [8]. With a pKa value of 9.2, $\mathrm{NH}_{4}{ }^{+}$is the overwhelming form in the chemical equilibrium between $\mathrm{NH}_{3}$ (ammonium) and $\mathrm{NH}_{4}{ }^{+}$(ammonia) at the slightly acidic $\mathrm{pH}$ values within the ruminal content. The expression of this channel in the bovine ruminal epithelium makes it a good candidate as the (or one of the) transport proteins for $\mathrm{NH}_{4}{ }^{+}$. Ammonia is rapidly absorbed from the forestomach, converted to urea in the liver and recycled into the forestomach as substrate for microbial protein synthesis or excreted via the urine. Probably, TRPV3 is also the molecular basis for the long-known divalent-sensitive cation conductance found in the forestomach epithelium [10].

Transport of $\mathrm{NH}_{4}^{+} / \mathrm{NH}_{3}$ has up to now thought to be mediated by simple non-ionic diffusion of the gas $\mathrm{NH}_{3}$ or by renal rhesus-associated glycoproteins, members of the SLC42 solute transporter family able to transport both $\mathrm{NH}_{4}{ }^{+}$ and $\mathrm{NH}_{3}$ [1]. Furthermore, many $\mathrm{K}^{+}$channels and transporters accept $\mathrm{NH}_{4}^{+}$instead of $\mathrm{K}^{+}$due to the similar hydrated radius $(1.45 \AA)$ of both ions [6]. This property has been elegantly used in transport physiological studies to measure e.g. activity of $\mathrm{Na}^{+}-\mathrm{K}^{+}-2 \mathrm{Cl}^{-}$-transporters (NKCC) via bumetanide-

This article is a commentary to the original article https://doi.org/10.1007/ s00424-020-02393-2

Martin Diener

Martin.Diener@vetmed.uni-giessen.de

1 Institute for Veterinary Physiology and Biochemistry, Justus Liebig University Giessen, Frankfurter Str. 100, 35392 Giessen, Germany sensitive acidification in the presence of extracellular $\mathrm{NH}_{4}{ }^{+}$ $[5,7]$.

The present study of Liebe et al. now adds a new player, bTRPV3, to the list of transporters involved in ammonia transport. When regarding the biophysical properties of this unselective cation channel, bTRPV3 shows a remarkably high permeability for $\mathrm{N}$-methyl-D-glucamine ${ }^{+}\left(\mathrm{NMDG}^{+}\right)$, which is often used as 'impermeant' ion during cation substitution experiments. Despite the large molecular size of $\mathrm{NMDG}^{+}$, which is estimated to cover a volume of $6 \AA \times 6 \AA \times 12.5 \AA$ [4], fitting of shifts in zero-current potential during ion replacement experiments to the Goldman-Huxley-Katz equation revealed a permeability for $\mathrm{NMDG}^{+}$of about $45 \%$ in comparison with that for $\mathrm{Na}^{+}$. Due to these properties and its permeability even for divalent cations such as $\mathrm{Ca}^{2+}$, demonstrated by the same research group [9], it is well possible that beside ammonia absorption, also other absorptive functions of the ruminal epithelium may involve TRPV3.

The study of Liebe et al. has relevance for several fields. Production of climate gases such as $\mathrm{N}_{2} \mathrm{O}$ from cattle urine (starting from urea produced during the hepatic metabolism of $\mathrm{NH}_{4}{ }^{+}$absorbed by the forestomach) is a severe environmental problem [2]. So, basic knowledge about the physiological mechanisms of ruminal $\mathrm{NH}_{4}{ }^{+}$absorption delivering the substrate for urea production is urgently needed. A further outlook of the present study is the question whether TRPV3 or similar channels may be involved in the absorption of $\mathrm{NH}_{4}{ }^{+}$ from the large intestine such as caecum or colon, where also significant amounts of ammonium are absorbed. Healthy individuals protect their central nervous system from $\mathrm{NH}_{3} / \mathrm{NH}_{4}{ }^{+}$ by hepatic conversion into urea; any hepatic failure can therefore lead to encephalopathy. As many members of the superfamily of TRP channels can be pharmacologically activated or inhibited by different drugs or natural compounds (see [3]), these channels might be promising candidates for new therapeutic strategies. 
Funding Open Access funding enabled and organized by Projekt DEAL.

Open Access This article is licensed under a Creative Commons Attribution 4.0 International License, which permits use, sharing, adaptation, distribution and reproduction in any medium or format, as long as you give appropriate credit to the original author(s) and the source, provide a link to the Creative Commons licence, and indicate if changes were made. The images or other third party material in this article are included in the article's Creative Commons licence, unless indicated otherwise in a credit line to the material. If material is not included in the article's Creative Commons licence and your intended use is not permitted by statutory regulation or exceeds the permitted use, you will need to obtain permission directly from the copyright holder. To view a copy of this licence, visit http://creativecommons.org/licenses/by/4.0/.

\section{References}

1. Caner T, Abdulnour-Nakhoul S, Brown K, Islam MT, Hamm LL, Nakhoul NL (2015) Mechanisms of ammonia and ammonium transport by rhesus-associated glycoproteins. Am J Physiol Cell Physiol 309:C747-C758. https://doi.org/10.1152/ajpcell.00085. 2015

2. Chadwick DR, Cardenas LM, Dhanoa MS, Donovan N, Misselbrook TJ, Williams JR, Thorman RE, KL MG, Watson CJ, Bell M, Anthony SG, Reese RM (2018) The contribution of cattle urine and dung to nitrous oxide emissions: quantification of country specific emission factors and implications for national inventories. Sci Total Environ 635:607-617. https://doi.org/10.1016/j. scitotenv.2018.04.152
3. Concise Guide to Pharmacology (2020) http://www. guidetopharmacology.org/ (visited ApriL, 22, 2020)

4. Harkat M, Peverini L, Cerdan AH, Dunning K, Beudez J, Martz A, Calimet N, Specht A, Cecchini M, Chataigneau T, Grutter T (2017) On the permeation of large organic cations through the pore of ATP-gated P2X receptors. Proc Natl Acad Sci USA 114:E3786E3795. https://doi.org/10.1073/pnas.1701379114

5. Heitmann D, Warth R, Bleich M, Henger A, Nitschke R, Greger R (2000) Regulation of $\mathrm{Na}^{+} 2 \mathrm{Cl}^{-} \mathrm{K}^{+}$cotransporter in isolated rat colon crypts. Pflügers Arch Eur J Physiol 439:378-384. https://doi.org/ 10.1007/s004249900156

6. Knepper MA, Packer R, Good DW (1989) Ammonium transport in the kidney. Physiol Rev 69:179-249

7. Reynolds A, Parris A, Evans LA, Lindqvist S, Sharp P, Lewis M, Tighe R, Williams MR (2007) Dynamic and differential regulation of NKCC1 by calcium and cAMP in the native human colonic epithelium. J Physiol 582:507-524. https://doi.org/10.1113/ jphysiol.2007.129718

8. Reynolds CK, Kristensen NB (2008) Nitrogen recycling through the gut and the nitrogen economy of ruminants: an asynchronous symbiosis. J Anim Sci 86(Suppl. 14):E293-E305. https://doi.org/ 10.2527/jas.2007-0475

9. Schrapers KT, Sponder G, Liebe F, Liebe H, Stumpff F (2018) The bovine TRPV3 as a pathway for the uptake of $\mathrm{Na}^{+}, \mathrm{Ca}^{2+}$, and $\mathrm{NH}_{4}^{+}$. PLoS One 13:e0193519. https://doi.org/10.1371/journal.pone. 0193519

10. Schultheiss G, Martens H (1999) Ca-sensitive Na transport in sheep omasum. Am J Physiol 276:G1331-G1344. https://doi.org/10. 1152/ajpgi.1999.276.6.G1331

Publisher's note Springer Nature remains neutral with regard to jurisdictional claims in published maps and institutional affiliations. 